\title{
Panetti v. Quarterman: Mental Illness, the Death Penalty, and Human Dignity
}

\author{
Richard J. Bonnie* \\ I. INTRODUCTION
}

My assignment is to comment on the Supreme Court's 5-4 decision in Panetti v. Quarterman, ${ }^{1}$ holding that a delusional mentally ill prisoner who is aware that the State intends to execute him based on his conviction for a capital crime is not, based on that finding alone, competent for execution under the Eighth Amendment. In so doing, the Court rejected the contrary position taken by the Fifth Circuit and remanded the case for further proceedings. Does this obscure ruling carry any freight? It has all the earmarks of a one-off end-of-term decision with little significance for anyone other than a few very ill condemned prisoners: it deals with an issue that arises rarely, is doctrinally narrow, and has little connection with other domains of criminal or constitutional jurisprudence.

Indeed, most Court-watchers probably view Panetti as just another in the unending series of 5-4 decisions by a polarized Supreme Court that will continue, like the federal budget deficit, well into the twenty-first century. In this context, Panetti also confirms Justice Anthony Kennedy's personal prerogative, as the "swing vote" on this otherwise evenly divided Court, to declare the "supreme law of the land" as well as his predilection for doing so in a "minimalist" manner. Indeed, Justice Kennedy's majority opinion and Justice Thomas's dissent document the argumentative style (the Justices, like the parties, agree on nothing) that has become commonplace in the Court's decisions. Perhaps Panetti v. Quarterman does not warrant our attention at all.

To the contrary, the Panetti litigation highlights two deeply troubling problems in death penalty adjudication. First, it exposes the utter failure of the criminal justice system to take adequate account of the effects of severe mental illness in capital cases, specifically by failing to assure a fair defense for defendants with mental disabilities, by failing to give morally appropriate mitigating effect to claims of diminished responsibility at the time of the crime, and by failing to correct these deficiencies in post-conviction proceedings. Indifference to claims of incompetence on the eve of execution is only the last link in a long chain of indifference and neglect.

* Harrison Foundation Professor of Medicine and Law and Hunton Williams Research Professor, Professor of Psychiatry and Neurobehavioral Sciences, and Director, Institute of Law, Psychiatry and Public Policy, University of Virginia.

127 S. Ct. 2842 (2007). 
The problems associated with mental illness and the death penalty have become so widely recognized that the American Bar Association, the American Psychiatric Association, the American Psychological Association, and the National Alliance on Mental Illness have been moved to adopt identical resolutions aiming to assure fair treatment of individuals with mental disabilities in capital cases. ${ }^{2}$ These resolutions urge legislatures and courts to preclude death sentences for defendants who meet specified criteria of diminished responsibility, to assure that post-conviction proceedings in capital cases are suspended when the severely disturbed prisoner's personal participation is needed for a fair resolution of the issues, and to prevent execution of prisoners whose capacity to appreciate the nature and purpose of the punishment is significantly impaired. The Supreme Court's decision in Panetti, however closely divided and obscure, will reinforce the importance and urgency of these initiatives. Although his opinion does not mention these developments, I suspect that Justice Kennedy was well aware of this wider political context of the Panetti decision.

The second problem highlighted by the Panetti litigation is the futility of the Supreme Court's post-Furman ${ }^{3}$ capital sentencing jurisprudence. The death penalty defense bar may draw some hope from its success in delaying Panetti's execution. However, the Panetti litigation, seen in its entirety, illustrates the unwillingness of the Texas courts to take the necessary steps to assure the "heightened need for reliability" in capital adjudications. Ultimately the success of the Court's post-Furman project depends upon serious and sustained efforts by state appellate courts to implement the Eighth Amendment principles and values enunciated by the Supreme Court for the last three decades. The Panetti record

2 See ABA Task Force on Mental Disability and the Death Penalty, Recommendation and Report on the Death Penalty and Persons with Mental Disabilities, 30 MENTAL AND PHYSICAL DISABILITY L. REP. 668 (2006). The Resolution was developed by the ABA Task Force on Mental Disability and the Death Penalty, established by the ABA's Section on Individual Rights and Responsibilities and was approved in identical position statements adopted by the respective mental health organizations. See AMERICAN Psychiatric AsSOCIATION, DIMINISHEd ResPONSIBILITY IN CAPITAL SENTENCING (2004), available at http://www.psych.org/edu/other_res/lib_archives/archives/200406.pdf; AMERICAN PSYCHIATRIC

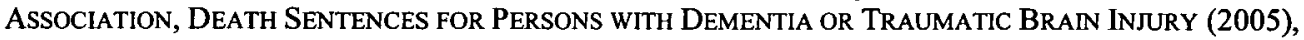
available at http://www.psych.org/edu/other_res/lib_archives/archives/200508.pdf; AMERICAN Psychiatric Association, Mentally Ill PRISOners ON Death Row (2005), available at http://www.psych.org/edu/other_res/lib_archives/archives/200505.pdf. See also American Psychological Association, Excerpt from the Council of Representatives 2005 Meeting Minutes (Feb. 18-20, 2005); American Psychological Association, Excerpt from the Council of Representatives 2006 Meeting Minutes (Feb. 17-19, 2006). I am obliged to disclose that I served on the ABA Task Force and was the principal architect of the portions of the Task Force Report relating to mentally ill prisoners (paragraph 3 of the resolution). See Richard J. Bonnie, Mentally Ill Prisoners on Death Row: Unsolved Puzzles for Courts and Legislatures, 54 CATH. U. L. REv. 1169 (2005). I should also disclose that I participated in the drafting of the amicus brief submitted in support of Panetti by the three mental health organizations. See Brief for American Psychological Association et al., as Amici Curiae Supporting Petitioner, Panetti v. Quarterman, 127 S. Ct. 2842 (2007) (No. 06-6407).

3 Furman v. Georgia, 408 U.S. 238 (1972). 
reveals how unwilling the Texas courts have been to do so (and they are, sadly, not alone), and how difficult it has become for federal courts to vindicate the values of the Eighth Amendment.

My commentary will proceed as follows: First, I will review the proceedings at trial, documenting the remarkable failure of the Texas courts to protect the dignity of the criminal process and assure a fair trial. Then I will turn to the litigation regarding Panetti's competence for execution, commenting on the impediments to federal court review under the Antiterrorism and Effective Death Penalty Act of 1996 (AEDPA), and then exploring the Court's holding on the merits and its rationale, as explained by Justice Kennedy. After setting forth my own views about the most persuasive grounding for the ban against executing incompetent prisoners, I will close by locating the Panetti decision in its larger context.

\section{PANETTI'S COMPETENCE AT TRIAL}

It is painful to read the record in Panetti's case. ${ }^{4}$ His lengthy history of severe mental illness is well-documented. He had been involuntarily committed to psychiatric hospitals in Texas and Wisconsin more than a dozen times during the decade preceding the crime. The recurrent diagnoses were chronic schizophrenia and schizoaffective disorder, characterized by tangential and circumstantial thinking, hallucinations, delusions, grandiosity and paranoia, with acute psychotic exacerbations complicated by alcohol use. Over time, his paranoid delusions became more pronounced. Throughout this long period of chronic illness, there was no suggestion of malingering. Even after his arrest, the psychiatrist who evaluated his competence to stand trial (in November, 1992) acknowledged Panetti's "chronic delusions, occasional hallucinations and an odd fragmentation of his personality," while concluding that he understood the charges against him and "appeared to be able to assist in his own defense and to process the information and questions given to him" in the course of two interviews.

Some people with chronic schizophrenia and other major mental disorders have sufficient capacity to assist in their own defense in a criminal adjudication despite significant cognitive impairments, and it may be fair to proceed with the prosecution in such cases as long as defense counsel is aware of the defendant's impairments and is able to carry out his or her own tasks adequately. It appears clear, however, that Panetti's thought disorder was so severe that, even with medication, he was unable to communicate rationally with his lawyers, one of

4 See Brief of Petitioner, Panetti v. Quarterman, 127 S. Ct. 2842 (2007) (No. 06-6407) [hereinafter, Brief of Petitioner]; Joint Appendix, Panetti v. Quarterman, 127 S. Ct. 2842 (No. 066407) [hereinafter, Joint Appendix].

5 Joint Appendix, supra note 4, Vol. I at 9. 
whom later testified that he had never had a meaningful and rational conversation with Panetti about the legal issues in the case. ${ }^{6}$

Panetti's lawyers had little choice except to challenge his competence to proceed. Under Texas law, competency proceedings are held before a jury. ${ }^{7}$ After hearing the opposing testimony of two psychiatrists, the jury deadlocked at 9-3 in favor of finding Panetti incompetent, and the judge declared a mistrial. After a change in venue, Panetti was found to be competent at a second competence trial. ${ }^{8}$

Seven months later, Panetti experienced what he called an "April Fool's Day revelation" that God had cured his schizophrenia, and he suddenly stopped taking his anti-psychotic medication. ${ }^{9}$ His already severe condition worsened. Most significantly, his paranoid ideation swent his lawyers into the zone of suspicion and distrust, and he eventually sought to fire them and represent himself under Faretta $v$. California. ${ }^{10}$ His attorneys vehemently objected. Although the federal habeas record is sketchy, it appears that the trial judge did not hold a hearing on Panetti's competence to proceed to trial, with or without counsel, and allowed him to waive his right to counsel and represent himself.

Even if Panetti had been marginally able to assist counsel a year earlier, it seems highly doubtful that he was able to do so at this point-his abilities to communicate rationally and to exercise judgment were substantially impaired by paranoid delusions and by pervasive cognitive confusion. Notwithstanding the jury's previous finding that Panetti was competent, the trial court has a continuing constitutional obligation to reconsider the question based on the defendant's condition and behavior. ${ }^{11}$ At the very least, the trial court should have suspended the proceedings to allow an inpatient evaluation of Panetti's competence to stand trial. However, even if Panetti remained competent to proceed to trial with counsel, he appears to have lacked the capacity to make a rational decision regarding self-representation and to make the decisions required of a defendant representing himself in a capital prosecution; indeed, his fragile mental and emotional condition seems to have worsened as the trial went on. He lacked a "rational understanding" of the very task of self-representation and of the decisions that he was called on to make because he did not appreciate their significance or consequences. Yet, without even seeking further evaluation or holding a new hearing, the trial judge ruled that Panetti was competent to waive counsel and represent himself, and the trial went forward.

The Supreme Court record includes two of the documents submitted in the first federal habeas proceedings - affidavits by Scott Monroe, Panetti's stand-by

\footnotetext{
6 Brief of Petitioner, supra note 4, at 7.

TeX. Code CrIM. Proc. ANN. art. 46B.051(a) (1965).

Brief of Petitioner, supra note 4, at 9.

Id. at 10 .

10422 U.S. 806 (1975).

11 Drope v. Missouri, 420 U.S. 162, 171-73 (1975).
} 
counsel at his trial, and Dr. Wolfgang Selck, a psychiatrist who had treated Panetti when he was hospitalized in 1986 and who observed him at his trial in 1992." Taken together, these affidavits show, as Monroe put it, that Panetti's "trial was truly a judicial farce, and a mockery of self-representation. It should have never been allowed to happen ..."13 For example, Panetti sent all the files prepared by counsel to his family in Wisconsin to keep the jail guards form seeing them, and never looked at them; he subpoenaed more than 200 witnesses, including Jesus Christ, John F. Kennedy and other dead people; he completely ignored the annotated materials on the law prepared by Monroe; he paid little attention to jury selection; and he never took advantage of the occasional "pow-wows" granted by the court to enable him to consult with Monroe, choosing instead to smoke a cigar. $^{14}$ Panetti put on no case in mitigation whatsoever, notwithstanding his history of mental illness and the availability of many witnesses who could testify about the effects of his illness, and the deterioration of his condition.

Panetti's behavior at his trial was bizarre, to put it mildly. He dressed in cowboy garb, spoke in a TV western vernacular, and behaved as if he were acting in a drama. When he testified, he assumed the personality of "Sarge" and "recalled in [a] trance-like state, the details of the shooting, reciting what happened in the third person as a dialogue" judge was prompted to say, "Mr. Panetti, let's stop." 16 To anyone who has any understanding of the debilitating effects of severe mental illness and any respect for the dignity of the judicial process, this must have been a painful and distressing spectacle. As Dr. Selck observed, Panetti "literally enjoyed the spectacle of the Courtroom where he was the center of attention and was being allowed to act like an attorney." 17 Sadly, though, he "was acting out a role of an attorney as a facet of the mental illness, not a rational decision to represent himself at trial." ${ }^{\prime 18}$ For Dr. Selck, Panetti's rambling speech and bizarre behavior "reflected a break from reality" and provided clear evidence of mental illness. ${ }^{19}$ However, he observed, "I suspect that the members of the jury ... saw Scott and thought he was normal and pretending to be mentally ill," ${ }^{20}$ in support of an insanity plea. Is it any wonder that a jury would show little sympathy for a self-absorbed defendant mocking the court by pretending to be mentally ill?

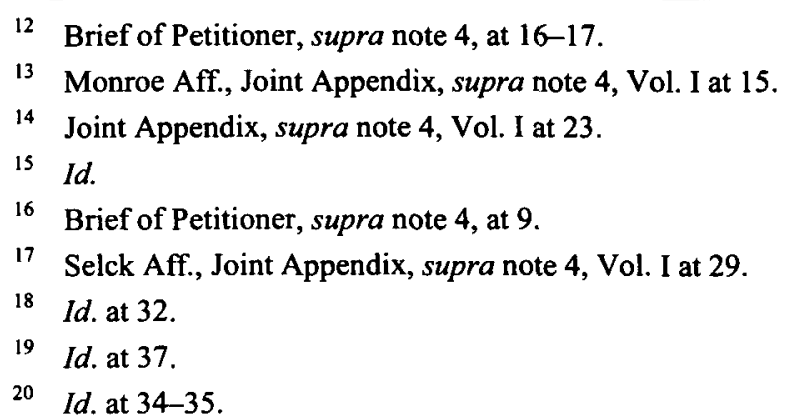


Courts trivialize mental illness, disserve the important principle of autonomy protected by Faretta, and compromise the dignity of the law when they allow defendants as disturbed as Panetti to represent themselves in criminal trials. It is horrifying that judges would allow such a spectacle in a capital trial-even if the defendant fails to recognize that his behavior imperils his life, the courts should have no such illusions. How could they allow this?

One possible answer is that they think the Supreme Court has required them to do so. The problem may lie in the Court's misguided 1993 decision in Godinez v. Moran, ${ }^{21}$ holding that a defendant who has been found to be competent to stand trial is also competent to plead guilty and to waive counsel. As I have discussed elsewhere, ${ }^{22}$ the issue raised in Gndinez was nresented to the Court in a misleading way-i.e., whether the test for competence to plead guilty was "higher than" the test for competence to stand trial-and the Court went out of its way to emphasize that there is only one test for competence to proceed in a criminal case.

The Court was right about the typical case. As long as the unitary test for adjudicative competence encompasses the capacity to make informed decisions, as the Godinez decision implies, then there should be no difference between the tests for pleading guilty or going to trial. The important issue in those contexts is a readiness to reopen the question of competence whenever the defendant's behavior raises a good faith doubt about his or her capacity, even on the eve of trial or at the time of a plea. All of this is consistent with the Court's decision in Godinez.

Where the Court went astray in Godinez, however, is in ruling that a defendant who is competent to assist counsel is, ipso facto, competent to proceed without counsel or to make other consequential decisions over counsel's objection. In these contexts, it is not enough that the defendant has an adequate understanding of the charges and proceedings and that he is able to communicate rationally with counsel and make informed decisions. The measure of capacity should be more particularized in this context, taking into account the stakes of proceeding without counsel and the jeopardy to which the unrepresented defendant is exposed. ${ }^{23}$ Accordingly, to use the language of Dusky v. United States, ${ }^{24}$ the defendant must have a "rational as well as factual understanding" of the potential consequences (risks and benefits) of the specific decision. If he does not, he may simultaneously be competent to proceed to trial with the assistance of counsel, but not to waive counsel and represent himself. This approach has the advantage of allowing the criminal process to continue in cases where the defendant is competent to understand the proceedings and to assist counsel while avoiding the morally troubling outcomes produced when severely disturbed defendants are allowed to

21509 U.S. 389 (1993).

22 Richard J. Bonnie, The Competence of Criminal Defendants: Beyond Dusky and Drope, 47 U. MiAMI L. REV. 539, 587-93 (1993).

23 Id. at 567-87.

24362 U.S. 402 (1960). 
represent themselves or otherwise undermine their best legal interests. ${ }^{25}$ Respect for autonomy under Faretta does not require the courts to allow defendants as disturbed as Panetti to dig their own graves.

It is gruesomely ironic that, less than two months after Panetti was sentenced to death, the trial court found him incompetent to waive the appointment of counsel to represent him in post-conviction proceedings. Thus, a severely disturbed capital defendant was allowed to forsake at trial every legal protection afforded by the law, including his right to counsel, while his desire to proceed pro se thereafter was overridden. Is it too cynical to attribute the trial court's otherwise puzzling decisions to a desire to secure a death sentence and then to insulate it from reversal in post-conviction review? Whatever the explanation, the death sentence was undisturbed on collateral review by both the state and federal courts in the face of claims that Panetti had been incompetent to stand trial or to waive his right to counsel and represent himself.

\section{FEDERAL JURISDICTION TO CONSIDER THE FORD CLAIM}

After the conviction and sentence were upheld on collateral review, the trial court set an execution date, and Panetti filed a motion to stay the execution on the ground that he was incompetent to be executed under Ford v. Wainwright. ${ }^{26}$ After that motion was denied, Panetti filed a second federal habeas petition raising his Ford claim. When the federal court took up the matter several months later (after the state court had rejected a renewed Ford motion), the State claimed that the federal court lacked jurisdiction to adjudicate Panetti's Ford claim. The State relied on 28 U.S.C. $\S 2244(b)(2)$, which requires dismissal of "a claim presented in a second or successive habeas corpus application . . . that was not presented in a prior application" except under certain, narrow circumstances not applicable here. $^{27}$

It is clearly established, as the State conceded, that a Ford claim is not ripe for adjudication until an execution date has been set, and it would have been premature for Panetti to raise it in his first federal habeas petition. Thus, the State's argument was that Panetti's failure to raise an admittedly premature claim in his first habeas petition should forever bar the federal courts from vindicating his constitutional right not to be executed while incompetent. On the face of it, this argument is hard to take seriously. Its practical effect would be to force all prisoners under sentences of death to include pro forma Ford claims in their state and federal habeas petitions in order to preserve them for later review in the event

25 The most pertinent illustration of the problem is when a capital defendant instructs counsel to refrain from introducing mitigating evidence in the sentencing phase of a capital case. See Richard J. Bonnie, The Dignity of the Condemned, 74 VA. L. REV. 1363 (1988).

26477 U.S. 399, 410 (1986) (holding that the Eighth Amendment bars states "from carrying out a sentence of death upon a prisoner who is insane").

2728 U.S.C. $\$ 2244($ b)(2) (2000). 
that a plausible question actually arises, and to require the courts to dispose of these unripe, and usually meritless, claims. Even worse, it would foreclose valid execution-competence claims on behalf of prisoners whose habeas lawyers were (blamelessly) unaware of the peculiar obligation to raise a claim prematurely (perhaps years prematurely and with no present factual basis) in order to avoid forfeiting it.

Why did the Court take the State's argument seriously? The argument "has some force," 28 Justice Kennedy acknowledged, because the language of 28 U.S.C. $\S 2244(b)(2)$ (2000) literally bars consideration of any claim that was not raised in Panetti's first habeas petition and provides no exception for presently unripe claims. $^{29}$ Indeed. the argument was thought to have persuasive force by the four Panetti dissenters who regarded the "plain meaning" of the statute to be controlling. ${ }^{30}$

Fortunately, the majority was willing to see a latent ambiguity in the statutory language and concluded that Congress "did not intend the provisions of AEDPA addressing 'second or successive' petitions" to apply "to a Ford claim brought in an application filed when the claim is first ripe." 31 As Justice Kennedy pointed out, the AEDPA restriction on "second or successive" federal habeas petitions was designed to protect the finality of state court judgments regarding conviction and sentence and was not intended to preclude the filing of a petition relating to the vindication of federal constitutional rights that arise at the time of execution. ${ }^{32}$ Thus, he noted, "we are hesitant to construe a statute, implemented to further the principles of comity, finality, and federalism, in a manner that would require unripe (and, often, factually unsupported) claims to be raised as a mere formality, to the benefit of no party." 33

It is both perplexing and disturbing that four justices were prepared to hold that the federal courts have no jurisdiction under the AEDPA to adjudicate a Ford claim that was presented to the state and federal courts only after the claim became ripe for adjudication. Justice Thomas's wooden reasoning so thoroughly ignores the context and consequences of the result it reaches that it can be explained only by utter indifference to the values at stake in Ford claims and a rigid adherence to a misguided view of statutory interpretation.

28 Panetti v. Quarterman, 127 S. Ct. 2842, 2852 (2007).

29 See id. at 2855.

$30 \quad$ Id. at 2867.

31 Id. at 2855.

$32 \quad I d$ at 2854.

33 Id. at 2855. 


\section{DEFERENCE To THE STATE COURT DECISION UNDER THE AEDPA}

Panetti filed his first Ford motion in state court on December 9, 2003. ${ }^{34}$ It was accompanied by several lengthy affidavits, including two from habeas counsel, attesting to Panetti's severe symptoms of mental illness over the past few years. ${ }^{35}$ The state court denied the motion on December 23, on the ground that Panetti had "failed to set forth alleged facts in support of the assertion that [he] is presently incompetent." ${ }^{36}$ On February 4, at the direction of the federal district court, Panetti sought renewed consideration of his motion by the state court and accompanied the motion with affidavits from a forensic clinical psychologist and a law professor who both had observed Panetti in recent days and concluded that he was experiencing delusions that prevented him from understanding why he was being executed.

After concluding that Panetti had now made "a substantial showing of incompetency," within the meaning of the governing state statute, the state judge appointed two mental health experts to evaluate Panetti. ${ }^{37}$ In their joint report, filed on April 28, they opined that, even though Panetti had declined to answer their questions during the interview, he "has the ability to understand the reason he is to be executed" and is competent to be executed. ${ }^{38}$ Panetti's counsel thereafter filed numerous objections to the methods and conclusions of the court-appointed experts, renewed his previous motions for appointment of counsel and funds to hire a defense expert, and requested a hearing. However, on May 26, without either scheduling argument on the defense motions or holding a hearing, the state court denied the motions and ruled that Panetti had failed to show that he was incompetent. ${ }^{39}$ No appeal was available to Panetti under state law.

There are two major hurdles for state prisoners in federal habeas litigation. One is getting the federal courts to address the merits of claims that were not raised at trial. ${ }^{40}$ (At least that is one hurdle Panetti did not have to overcome; even Texas did not argue that an execution competence claim had to be preserved at trial to avoid forfeiture.) The second is overcoming the strong deference given to state court judgments. Here, the state trial court had found that Panetti had "failed to show, by a preponderance of the evidence, that he is incompetent to be executed." ${ }^{41}$ The federal courts are obliged to defer to this judgment unless the state court proceedings "resulted in a decision that was contrary to, or involved an

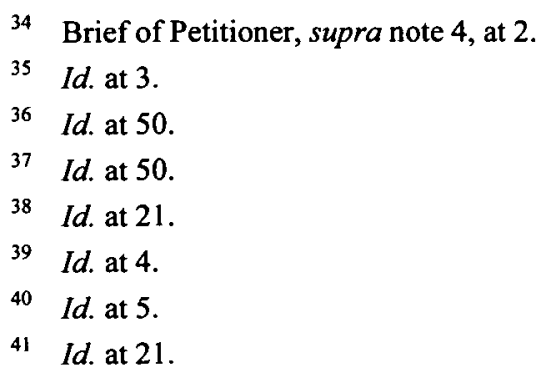


unreasonable application of, clearly established Federal law, as determined by the Supreme Court of the United States" or "was based on an unreasonable determination of the facts in light of the evidence presented at the state court proceedings." 42

In order to escape the state court's judgment, Panetti had two possible lines of attack, both stemming from Ford, the sole applicable decision of the United States Supreme Court. The first was substantive-that the state court finding rested (implicitly, since the state court never explained its ruling) on a clearly mistaken application of the substantive rule announced in Ford. In effect, Panetti would have to persuade the Supreme Court not only that the Fifth Circuit's definition of competence to be executed, first enunciated in Barnard $v$ Collins, ${ }^{43}$ was erroneous, but also that it was contrary to law "clearly established" in Ford.

Panetti's brief argues that an inmate must have a "rational understanding" of the reason for the execution under any of the rationales for the common-law rule against executing the incompetent that had been constitutionalized in Ford. ${ }^{44}$ The legal historians' amicus brief makes a similar argument. ${ }^{45}$ This might be the best reading of Ford, but it cannot be said that it is the only plausible reading. Neither the Ford plurality opinion by Justice Marshall, nor Justice Powell's concurring opinion, articulated a "rational understanding" standard, and the scattered common-law precedents and commentaries acknowledge the ban against executing "insane" prisoners but provide no reference to any particular "test." The one thing about Ford that is clear is that no test was announced.

Panetti's second line of attack on the state court judgment is based on the Supreme Court's procedural due process ruling in Ford, which invalidated Florida's gubernatorial decision-making process for deciding whether a condemned prisoner is insane. Federal district court judge Sparks was persuaded that the state court's refusal to give Panetti an opportunity to contest the courtordered examiners' joint opinion or to obtain an opinion by another expert " $\mathrm{fl}[\mathrm{ew}]$ in the face of ... Ford... [where] seven Justices of the Supreme Court concluded [that] denying a petitioner the right to present, as well as rebut, evidence in making a competency-to-be-executed determination violates the right to due process."46 Judge Sparks also concluded that the state court's failure to hold a hearing (as required under state law) erased the duty to defer to the resulting finding under a previous Fifth Circuit interpretation of Ford. Justice Kennedy embraced judge Sparks's approach ${ }^{47}$ to the AEDPA:

\footnotetext{
4228 U.S.C. $\$ 2245(d)$ (2000).

4313 F.3d 871 (5th Cir. 1994).

44 Brief of Petitioner, supra note 4, at 29.

45 Brief of Legal Historians at 16, Panetti v. Quarterman, 127 S. Ct. 2842 (2007) (No. 066407).

46 Panetti v. Dretke, 401 F. Supp.2d 702, 705 (W.D. Tex. 2004).

47 Because the Fifth Circuit affirmed judge Sparks's decision denying Panetti's claim on the merits, it did not address the AEDPA issue.
} 
We agree with petitioner that no deference is due. The state court's failure to provide the procedures mandated by Ford constituted an unreasonable application of clearly established law as determined by this Court. It is uncontested that petitioner made a substantial showing of incompetency. This showing entitled him to, among other things, an adequate means by which to submit expert psychiatric evidence in response to the evidence that had been solicited by the state court. And it is clear from the record that the state court reached its competency determination after failing to provide petitioner with this process, notwithstanding counsel's sustained effort, diligence, and compliance with court orders. As a result of this error, our review of petitioner's underlying incompetency claim is unencumbered by the deference AEDPA normally requires .... .

. . The state court failed to provide petitioner with a constitutionally adequate opportunity to be heard. After a prisoner has made the requisite threshold showing, Ford requires, at a minimum, that a court allow a prisoner's counsel the opportunity to make an adequate response to evidence solicited by the state court. In petitioner's case this meant an opportunity to submit psychiatric evidence as a counterweight to the report filed by the court-appointed experts. Yet petitioner failed to receive even this rudimentary process. ${ }^{48}$

The four dissenters insisted that the state court ruling was entitled to deference. The dissent implicitly acknowledged that the state court procedures would have been contrary to "clearly established law," if the governing law in Ford had appeared in Justice Marshall's opinion for the plurality-that opinion endorses the need for trial-type procedures for execution competence adjudications, and would require access to mental health assistance, a right to contest the state-provided exam, and the right to a hearing. However, the dissenters insisted that Justice Powell's pivotal concurring opinion did not clearly require either judicial decision-making or adversarial procedures. Thus, the disagreement in Panetti turns exclusively on whether the procedures provided by the Texas court reflected an "unreasonable application" of "clearly established law" as stated in Justice Powell's separate opinion in Ford.

So, what this disagreement between Justices Kennedy and Thomas appears to boil down to is (i) the correct interpretation of Justice Powell's concurring opinion in Ford and (ii) whether an expansive understanding could be said to have been "clearly established" by Powell himself before Justice Kennedy said so in Panetti. This exercise amounts to reading Justice Powell's mind when he wrote his separate opinion in Ford in 1986. It is doubtful that the votes of any of the nine justices actually turned on such an indeterminate inquiry. What seems most likely is that at least one vote (Justice Kennedy's), and perhaps more, turned on the justices'

48 Panetti v. Quarterman, 127 S. Ct. 2842, 2855 (2007). 
annoyance at the trial judge's demonstrable failure to take the Ford claim seriously. Justice Kennedy's characterization of the trial judge's inadequate treatment of the claim clearly demonstrates his irritation:

The state court refused to transcribe its proceedings, notwithstanding the multiple motions petitioner filed requesting this process. To the extent a more complete record may have put some of the court's actions in a more favorable light, this only constitutes further evidence of the inadequacy of the proceedings. Based on the materials available to this Court, it appears the state court on repeated occasions conveyed information to netitioner's counsel that turned out not to be true; provided at least one significant update to the State without providing the same notice to petitioner; and failed in general to keep petitioner informed as to the opportunity, if any, he would have to present his case. There is also a strong argument the court violated state law by failing to provide a competency hearing. If this did, in fact, constitute a violation of the procedural framework Texas has mandated for the adjudication of incompetency claims, the violation undermines any reliance the State might now place on Justice Powell's assertion that "the States should have substantial leeway to determine what process best balances the various interests at stake." ...

The state court made an additional error, one that Ford makes clear is impermissible under the Constitution: It failed to provide petitioner with an adequate opportunity to submit expert evidence in response to the report filed by the court-appointed experts. The court mailed the experts' report to both parties in the first week of May. The report, which rejected the factual basis for petitioner's claim, set forth new allegations suggesting that petitioner's bizarre behavior was due, at least in part, to deliberate design rather than mental illness. Petitioner's counsel reached the reasonable conclusion that these allegations warranted a response. On May 14 the court told petitioner's counsel, by letter, to file "any other matters you wish to have considered" within a week. Petitioner, in response, renewed his motions for an evidentiary hearing, funds to hire a mental health expert, and other relief. He did not submit at that time expert psychiatric evidence to challenge the courtappointed experts' report, a decision that in context made sense: The court had said it would rule on his outstanding motions, which included a request for funds to hire a mental-health expert and a request for an evidentiary hearing, once the court-appointed experts had completed their evaluation. Counsel was justified in relying on this representation by the court.

Texas law, moreover, provides that a court's finding of incompetency will be made on the basis of, inter alia, a "final competency hearing." ... Had the court advised counsel it would resolve 
the case without first ruling on petitioner's motions and without holding a competency hearing, petitioner's counsel might have managed to procure the assistance of experts, as he had been able to do on a pro bono basis the day before petitioner's previously scheduled execution. It was, in any event, reasonable for counsel to refrain from procuring and submitting expert psychiatric evidence while waiting for the court to rule on the timely filed motions, all in reliance on the court's assurances.

But at this point the court simply ended the matter. ${ }^{49}$

The trial court's failure to take Panetti's Ford claim seriously does not seem to have bothered Justice Thomas and his dissenting companions. Their opinion reflects a strong predisposition to defer to state court judgments, almost no matter how sloppy they may have been. What the majority characterizes as arbitrary and inconsiderate judicial conduct is seen by Justice Thomas as a lack of vigilance by counsel. This disagreement is likely grounded in strongly divergent views regarding the importance of the individual interest protected by Ford.

\section{THE HOLDING ON PANETTI's FORD ClAIM}

The starting point for addressing Panetti's claim on the merits is Justice Powell's observation in Ford that the Eighth Amendment "forbids the execution only of those who are unaware of the punishment they are about to suffer and why they are to suffer it." ${ }^{50}$ Justice Kennedy summarized the interpretation of Ford that guided the Court of Appeals as follows:

[T] he Court of Appeals identified the relevant District Court findings as follows: first, petitioner is aware that he committed the murders; second, he is aware that he will be executed; and, third, he is aware that the reason the State has given for the execution is his commission of the crimes in question. Under Circuit precedent this ends the analysis as a matter of law; for the Court of Appeals regards these three factual findings as necessarily demonstrating that a prisoner is aware of the reason for his execution. ${ }^{51}$ Ford:"

That holding, Justice Kennedy concluded, "rests on a flawed interpretation of

Circuit precedent required the District Court to disregard evidence of psychological dysfunction that ... may have resulted in petitioner's "fundamental failure to appreciate the connection between the

\footnotetext{
49 Panetti, 127 S. Ct. at 2856-58 (internal citations omitted).

50 Ford v. Wainwright, 477 U.S. 399, 422 (1986).

51 Panetti, 127 S. Ct. at 2860 (internal citations omitted).
} 
petitioner's crime and his execution." To refuse to consider evidence of this nature is to mistake Ford's holding and its logic. Gross delusions stemming from a severe mental disorder may put an awareness of a link between a crime and its punishment in a context so far removed from reality that the punishment can serve no proper purpose. It is therefore error to derive from Ford, and the substantive standard for incompetency its opinions broadly identify, a strict test for competency that treats delusional beliefs as irrelevant once the prisoner is aware the State has identified the link between his crime and the punishment to be inflicted. ${ }^{52}$

While rejecting the standard followed by the Court of Appeals, Justice Kennedy declined "to attempt to set down a rule governing all competency determinations" until Panetti's claims could be further developed on remand. ${ }^{53}$

On first reading, I found myself lamenting the Court's failure, once again, to embrace a substantive test of competence for execution. Another illustration of minimalist circumlocution by a justice who wants to decide no more than what is absolutely required to decide the case before him, I thought. However, upon further reflection, I have come to the view that by rejecting the "thin" test of incompetence deployed by the Fifth Circuit, the Supreme Court decided the most important issue, and signaled its likely support for a test of "rational understanding" without tying its hands in ways that it might regret in future cases. The fundamental problem with the Fifth Circuit's approach is that it fails to take account of the morally relevant clinical realities of severe mental illness, particularly the distortions of the mentally ill person's understanding of the meaning of his own behavior, as perceived by others, and of the meaning of, and motivation for, other people's behavior.

In this regard, Justice Kennedy's approach maps nicely onto the distinctions that courts have drawn in other contexts between "factual" understanding and "rational understanding" (competence to stand trial) s $^{54}$ or between "knowing" something to have been illegal and "appreciating its wrongfulness" (criminal responsibility). ${ }^{55}$ Purely formal understanding of the kind demonstrated by Panetti requires no more than the ability to articulate a semantic connection ("people who are convicted of crimes are sent to prison or executed"). However, psychotic decompensation associated with severe mental illness can leave such a formal

\footnotetext{
52 Id. at 2862 (internal citations omitted).

53 Id.

54 Dusky v. United States, 362 U.S. 402 (1960). For further discussion of the meaning and assessment of "rational understanding" in criminal defendants, see Bonnie, supra note 22, at 539, and NORMAN POYTHRESS ET Al., AdJUdiCATIVE COMPETENCE: The MACARTHUR STUdies (2002).

ss See Richard J. Bonnie et al., The Trial of John W. Hinckley, Jr.: A CaSe STUdy IN THE INSANITY DEFENSE (2000).
} 
understanding intact, while erasing or distorting a person's ability to recognize the meaning and significance of his behavior and the behavior of others. ${ }^{56}$

It is important to emphasize, as Justice Kennedy properly does, that the Ford prohibition aims to exempt only people with severe mental illness. In what may turn out to be one of the most important passages in the opinion, he highlights the critical distinction between severe mental disorders characterized by psychotic features and character pathology, most notably psychopathy:

[W]e must not ignore the concern that some prisoners, whose cases are not implicated by this decision, will fail to understand why they are to be punished on account of reasons other than those stemming from a severe mental illness. The mental state requisite for competence to suffer capital punishment neither presumes nor requires a person who would be considered "normal," or even "rational," in a layperson's understanding of those terms. Someone who is condemned to death for an atrocious murder may be so callous as to be unrepentant; so self-centered and devoid of compassion as to lack all sense of guilt; so adept in transferring blame to others as to be considered, at least in the colloquial sense, to be out of touch with reality. Those states of mind, even if extreme compared to the criminal population at large, are not what petitioner contends lie at the threshold of a competence inquiry. The beginning of doubt about competence in a case like petitioner's is not a misanthropic personality or an amoral character. It is a psychotic disorder. ${ }^{57}$

The psychopathic offender lacks the capacity for moral cognition and may not, for that reason, understand the moral connection between his wrongdoing and the punishment he is about to suffer. However, such an offender does have the capacity to understand that society draws that connection, and that he is being punished because society condemns the conduct for which he was convicted. Such cases are fundamentally different, in both clinical and moral terms, from cases, like Panetti's, in which the offender's patently false beliefs about official motivations for his impending execution are rooted in psychotic delusions.

\section{WHY NOT EXECUTE AN INCOMPETENT PRISONER?}

To say that the Court's decision takes account of the clinical realities of severe mental illness is not necessarily to say that it is the most sensible

56 See generally, Paul S. Applebaum \& Thomas Grisso, Assessing Patients' Capacities to Consent to Treatment, 319 NEw ENG. J. MED. 1635 (1988); Richard J. Bonnie, Morality, Equality, and Expertise: Renegotiating the Relationship Between Psychiatry and the Criminal Law, 12 BulL. AM. ACAD. PSYHCIATRY \& L. 5, 6 (1984).

57 Panetti, 127 S. Ct. at 2862. 
application of the Eighth Amendment. ${ }^{58}$ To put it bluntly, maybe a "thin" criterion of competence is adequate to protect the values at stake in execution competence adjudications, while the "thicker" criterion, however it might be defined, would needlessly increase the costs of administering the death penalty. Why, exactly, is the Fifth Circuit's test undesirable? In order to answer this question, it is necessary to go back to the holding in Ford itself. Why does the prisoner's mental condition at the time of the execution matter? ${ }^{59}$

In Ford, Justice Marshall set forth various rationales to which common-law authorities had referred, including recognition that "the execution of an insane person simply offends humanity," that it "provides no example to others," that "it is uncharitable to dispatch an offender into another world, when he is not of a capacity to fit himself for it," that "madness is its own punishment," and that executing an insane person serves no retributive purpose. ${ }^{60} \mathrm{He}$ then made the following observations about the contemporary grounding of the ancient ban:

[T]oday, no less than before, we may seriously question the retributive value of executing a person who has no comprehension of why he has been singled out and stripped of his fundamental right to life. . . . Similarly, the natural abhorrence civilized societies feel at killing one who has no capacity to come to grips with his own conscience or deity is still vivid today. And the intuition that such an execution simply offends humanity is evidently shared across this Nation. Faced with such widespread evidence of a restriction upon sovereign power, this Court is compelled to conclude that the Eighth Amendment prohibits a State from carrying out a sentence of death upon a prisoner who is insane. Whether its aim be to protect the condemned from fear and pain without comfort of understanding, or to protect the dignity of society itself from the barbarity of exacting mindless vengeance, the restriction finds enforcement in the Eighth Amendment. ${ }^{61}$

58 I am assuming for this purpose, as the Court did, that Panetti was competent to be tried and was responsible at the time of the offense. I am also assuming that his incapacity during the postconviction process was not an impediment to a fair adjudication of his habeas claims.

59 During the process of drafting the amicus brief for the various mental health associations, discussed in note 2, supra, members of the drafting team expressed concern about the persuasiveness of the argument being made for the "rational understanding standard" because the argument was not grounded in any legal argument about Ford or the Eighth Amendment. The argument was a bare claim that the Fifth Circuit's test failed to take account of the clinical realities of severe mental illness. The brief made no effort to go back and connect the dots between "rational understanding" and the rationale for the Ford rule. However, this would have been a difficult task because it would have required a theory about the reason for the Ford prohibition itself.

60 Ford v. Wainwright, 477 U.S. 399, 407-08 (1986).

${ }^{61} \quad$ Id. at 409. 
It was not necessary for the Ford Court to settle on any particular rationale since it needed to do nothing more than proclaim that the common-law prohibition is embedded in the Eighth Amendment. If the common-law courts and authorities had also embraced a particular criterion for incompetence to be executed, then it might follow that this definition is also embedded in the Eighth Amendment, without drawing the Court into any deeper exploration of the rationale for the prohibition than it undertook in Ford itself. However, this path was not open to the Court in Panetti because, as the legal historians' brief clearly documented, no definition of incompetence for execution was enunciated by the common-law authorities. ${ }^{62}$ Inevitably, then, in order to articulate a substantive constitutional standard, the Panetti Court needed to explore the rationales for the ban, as viewed through the lens of "the evolving standards of decency of a maturing society."63

Justice Kennedy took retribution as his starting point ${ }^{64}$ when he began to explore the compatibility of the Fifth Circuit's test with Ford:

Considering . . . whether retribution is served[,] it might be said that capital punishment is imposed because it has the potential to make the offender recognize at last the gravity of his crime and to allow the community as a whole, including the surviving family and friends of the victim, to affirm its own judgment that the culpability of the prisoner is so serious that the ultimate penalty must be sought and imposed. The

62 Brief of Legal Historians at 5, Panetti, 127 S. Ct. 2842 (No. 06-6407) ("History reveals no precise definitions or uniform standards used at common law to determine mental competency.").

63 Justice Kennedy's failure to explain why he focused the analysis on retribution highlights the lack of a methodological clarity in the opinion discussed by Carol Steiker. Carol Steiker, Panetti v. Quarterman: Is there a "Rational Understanding" of the Supreme Court's Eighth Amendment Jurisprudence?, 5 OHIO ST. J. CRIM. L. 285 (2007).

64 Justice Kennedy did not dwell on instrumental rationales for the ban, and I will make only a few passing observations. Regarding deterrence, Sir Edward Coke's suggestion that execution of a madman "can be no example to others," Ford, 477 U.S. at 407, (citing E. CoKE, THIRD INSTITUTE 6 (6th ed. 1680)), is demonstrably false; it might be no example to another madman, but anything that increases the probability of execution might enhance the deterrent effect of the death penalty. Whatever the general deterrent force of the death penalty may be under current conditions of enforcement, it is presumably enhanced by each execution, and might be enhanced even more by a publicized execution of a "madman" because it might demonstrate intensity of society's resolve.

Sir William Blackstone linked the prohibition to the possibility that "had the prisoner been of sound memory, he might have alleged something in stay of judgment or execution." Id. at 406 (citing William Blackstone, 4 Commentaries 24-25 (1769)). The possibility that an incompetent prisoner might have raised a valid legal objection to his execution might have been a significant one at the time Blackstone wrote his Commentaries 300 years ago when execution followed quickly after trial. However, this possibility is remote today in light of the extensive review of death sentences provided in both state and federal courts. Ford, 477 U.S. at 420 (Powell, J., concurring). It is possible to allow the post-conviction challenges to proceed in most cases even if the client's abilities to understand and assist in the proceedings are impaired (as was done in Panetti's own case). See ABA Task Force Report, supra note 2, at sections 3(b) and 3(c), and Richard J. Bonnie, Mentally Ill Prisoners on Death Row: Unsolved Puzzles for Courts and Legislatures, 54 CATH. U. L. REv. 1169 (2005). 
potential for a prisoner's recognition of the severity of the offense and the objective of community vindication are called in question, however, if the prisoner's mental state is so distorted by a mental illness that his awareness of the crime and punishment has little or no relation to the understanding of those concepts shared by the community as a whole. This problem is not necessarily overcome once the test set forth by the Court of Appeals is met.

$\cdots$

.. . The principles set forth in Ford are put at risk by a rule that deems delusions relevant only with respect to the State's announced reason for a punishment or the fact of an imminent execution, as opposed to the real interests the State seeks to vindicate. ${ }^{65}$

In the quoted passage, Justice Kennedy offers two different perspectives on the connection between a prisoner's mental condition at the time of execution and the retributive justification for punishment-a "subjective" perspective focusing exclusively on the prisoner's moral cognition and an "objective" perspective focusing on the community's response to such an execution. I will address them in reverse order:

[Execution] has the potential . . to allow the community as a whole ... to affirm its own judgment that the culpability of the prisoner is so serious that the ultimate penalty must be sought and imposed. ${ }^{66}$

This prong of Justice Kennedy's analysis is unconvincing. If the execution represents a reaffirmation of the community's retributive judgment (first registered at the time of the conviction and sentence) that the offender deserves to be executed, then why does his present mental condition have any bearing on that judgment? Surely the moral justification for the offender's punishment (indeed, under some views, the moral imperative of imposing it) remains grounded in the offender's culpability at the time of the offense. If anything is being reaffirmed at the time of execution, it is that the offender's culpable wrongdoing deserves the death penalty. Focusing on the offender's present "culpability" (if that is the right term) opens the door to claims of repentance, rehabilitation and current moral worthiness that are morally irrelevant from a retributive point of view. It also implicates the philosophically befuddling problem of identity-is the offender who is being executed the same "person" who committed the crime? Consider the moral basis for executing or otherwise punishing a murderer who has become moderately or severely demented in prison. Does his loss of memory for the offense and diminished moral agency now undermine the community's original judgment that death is a justly deserved punishment for the offense committed by

65 Panetti, 127 S. Ct. at 2861.

66 Id. at 2847 (emphasis added). 
the offender before he became demented? In sum, the Ford ban on executing persons who are presently incompetent cannot plausibly rest on the "objective" view enunciated by Justice Kennedy - that such executions would not allow the community to "reaffirm" the original retributive judgment.

\section{[Execution] has the potential to make the offender recognize at last the gravity of his crime. ${ }^{67}$}

This prong of Justice Kennedy's analysis implies that the retributive aim of the punishment is realized through the convict's own moral understanding of his wrongdoing at the time of the punishment. However compelling this claim may be in philosophical terms, its persuasiveness is weakened by the difficulty of squaring it with the actual practice of punishment.

First, it suggests that a criminal penalty would have no retributive force if it were imposed on a prisoner who believes, and insists until the very end, that his conduct was not wrongful. Such a prisoner would experience the penalty as pain but not as deserved "punishment." Perhaps this is why Justice Kennedy stops short of saying that subjective experience is the measure of a retributively justified punishment-he says that the punishment is retributively justified is it "has the potential to make the offender recognize at last the gravity of his crime." (emphasis added) But even this formulation is problematic because it would imply that the penalty has no retributive force if it is imposed on an offender who is demonstrably incapable (due for example, to grave character deficits) of acknowledging the "gravity of his crime." Execution would not even have retributive "potential" in such cases.

Perhaps it would be better to say that, even if the offender is not capable of recognizing that the penalty is a just response to his wrongdoing, it at least "has the potential to make the offender recognize" the intense anger or communal rage aroused by his wrongdoing. The offender is a "fit" subject for punishment if he knows or is able to know how the community views the gravity of his crime. This characterization would justify execution of the morally blind psychopath because carrying out the retributive act might "at last" impress upon him the depth of the community's outrage, whether or not he is capable of empathizing with family and friends of the victim.

This approach also implicates the important distinction drawn by Justice Kennedy between psychopathy and psychosis. If the retributive force of execution lies in social cognition (rather than moral cognition), the retributive goal of punishment would not be vindicated in Panetti's case because he (if believed) was not able to recognize the community's moral purpose in carrying out the execution. Indeed, he thought the community's purpose in carrying out his execution had nothing to do with his wrongdoing and was instead designed to suppress his preaching. The mere fact that he understands the formal connection between his

67 Id. (emphasis added). 
conviction and the execution does not establish that he has a rational understanding of the retributive aim of the execution-i.e., that it represents "punishment" for murder. In short, the moral foundation of punishment is lacking in the absence of a rational understanding of the nature and social purpose of the punishment - that it is punishment, that it will cause pain or, in this case, death, and that it is intended to be imposed in response to wrongdoing (and would not be imposed otherwise).

This "subjective" prong of the retributive argument does provide a plausible grounding for both Ford and Panetti. However, it lacks generalizability: it has some traction in the context of execution and other punishments, such as whipping, that exact retribution in a moment of pain or horror, but it does not map well, in my opinion, onto the standard liberty-constraining practices of criminal punishment in the modern world, most notably imprisonment. It implies, for example, that the time spent by a "presently incompetent" mentally ill prisoner in a psychiatric hospital (or, let it be said, untreated in the general population) does not "count" in retributive terms, and should not be credited toward service of his sentence. Of course, this is not (and should not be) the law.

\section{HUMAN DIGNITY}

I am personally unconvinced that the constitutional ban against executing a "presently incompetent" mentally ill prisoner is best understood, in contemporary terms, as being predicated on the idea that executing such a person serves no retributive purpose. In other words, I doubt that Ford, and its elaboration in Panetti, can be securely grounded in a bare philosophical assertion that the execution of an incompetent prisoner doesn't "count" as "punishment."

What, then, is the most sensible contemporary rationale for this long-standing feature of Anglo-American law? In Ford, Justice Marshall observed that the "execution of an insane person simply offends humanity,"68 and Justice Powell noted that it is "simply cruel" because "most men and women value the opportunity to prepare, mentally and spiritually, for their death[s]."69 These cryptic assertions reflect a fundamental ambiguity. Whose interests are protected by the bar against executing the incompetent? Do we prohibit this practice because it offends our own collective sensibilities about civilized behavior? Or do we prohibit this practice in order to respect the dignity of the condemned prisoner?

These interests are not necessarily congruent. Consider, by way of analogy, the trend toward supposedly more "humane" methods of execution, such as lethal injection. It is conceivable that a prisoner may find death by this method to be offensive to his own sense of dignity because it treats him as an object, like a dog being put to sleep; he may prefer to die by firing squad or on the gallows. When we sterilize the act of execution, do we do it for ourselves or for the prisoner?

68 Ford, 477 U.S. at $407-08$.

69 Id. at 421. 
If it is for us, the ban is rooted in the "ugh" factor-a squeamish reluctance to sully the dignity of the law by carrying out society's most powerful expression of condemnation on a child or a confused and incoherent madman. Executing a madman may have struck many spectators as a "cruel spectacle" when executions were public events. But now even the most delusional prisoner will be put to sleep rather than being held down under the blade of the axe. Today, it is the very idea of executing any human being that arouses disgust for many people, which is one reason why supporters of the practice have tried so hard to sanitize it and keep it out of public view. By avoiding the "cruel spectacle," however, these changes also reduce the emotional costs of carrying out executions, including the marginal cost of executing a madman.

If this prohibition has any continuing justification in the contemporary context, I believe it must be found in respect for the dignity of the condemned. The prisoner has a right, even under imminent sentence of death, to be treated as a person, worthy of respect, not as an object of the State's effort to carry out its promises. As Justice Powell suggested, a person under the shadow of death should have the opportunity to make the few choices that remain available to him. $\mathrm{He}$ should have the opportunity to decide who should be present at his execution, what he will eat for his last meal, what, if anything, he will utter for his last words, and whether he will repent or go defiantly to his grave. A prisoner who does not understand the nature and purpose of the execution is not able to exercise the choices that remain to him. To execute him in this condition is an affront to his dignity as a person and to the "dignity of man," the core value of the Eighth Amendment. $^{70}$

A "thin" veneer of formal understanding, which would be sufficient under the Fifth Circuit's test, ${ }^{71}$ is insufficient to respect the offender's dignity as a person. ${ }^{72}$ "Rational understanding" or "appreciation" of the nature and purpose of the punishment in the prisoner's own case is a satisfactory formulation of the "test" for competence to be executed. ${ }^{73}$ In Panetti's case, the record suggests that his competence for execution may have been impaired in more than one respect. First, by obscuring the State's purpose in executing him, his delusions may make him

70 Trop v. Dulles, 356 U.S. 86, 100 (1958).

71 Panetti v. Dretke, 448 F.3d 815 (5th Cir. 2006).

72 Under Kantian theory, punishment has no retributive force unless the person on whom it is carried out is a rational moral agent. See generally ImMANUEL Kant, THE METAPHYSICS OF MoRaLS, (Mary Gregor trans., Cambridge Univ. Press 1996). Although this is not the retributive theory enunciated by Justice Kennedy, it is congruent with my use of "respect for persons" as a limiting principle on otherwise justified punishment, whatever the theory of justification for that punishment.

73 Under paragraph 3(a) of the ABA Recommendation, "A sentence of death should not be carried out if the prisoner has a mental disorder or disability that significantly impairs his or her capacity ... (iii) to understand the nature and purpose of the punishment, or to appreciate the reason for its imposition in the prisoner's own case." Recommendations of the American Bar Association Section of Individual Rights and Responsibilities Task Force on Mental Disability and the Death Penalty, 54 CATH. U. L. REV. 1115,1115 (2005). 
unable to choose whether to accept responsibility for his wrongdoing; this is the feature of his condition that is implicated by the Fifth Circuit's ruling. However, his symptoms also probably impair his competence to be executed in another respect: his pervasive thought disorder probably prevents him from appreciating (beyond transient, momentary recognition) the permanent and solemn reality of execution. It is important to emphasize that the necessary understanding is about the finality of death, not about the possibility of a new or different "life" after death.

A person (whether or not mentally ill) who is confused or uncertain about the "afterlife" is, of course, not incompetent to be executed on that account-few of us would be competent for execution if that were so. Nor is a person who is certain that there is life after death incompetent to be executed on that account, even if he is also mentally ill. Competence for execution does not require the ability to "make peace with his or her Maker"74 or a desire or willingness to do so. However, a person whose mental illness precludes meaningful recognition of death as a marker between the "before" and the "after" is not competent to be executed. ${ }^{75}$

In Walton v. Johnson, ${ }^{76}$ the Fourth Circuit, sitting en banc, grappled with what Ford entails regarding the prisoner's understanding of what it means to die. The evidence showed that Percy Walton has borderline intelligence and is suffering from a severe mental disorder, probably schizophrenia. Although he was able to acknowledge that he was going to be "executed" and was going to "die," his statements that he expected to have a job at Burger King, and go to the shopping mall, after his execution raised a significant doubt regarding whether he had a meaningful understanding of what it means "to die." Six of the Fourth Circuit's judges would have remanded the case to the district court for a finding on whether Walton knew that his execution "will mean the end of his physical life."77 However, a seven-judge majority was unwilling to adopt any constitutional

74 C. Lee Harrington, A Community Divided: Defense Attorneys and the Ethics of Death Row Volunteering, 25 LAW \& Soc. INQUIRY 849, $852 \mathrm{n} .4$ (2000). In Ford, according to Hawles, it is uncharitable to dispatch an offender "into another world when he is not of a capacity to fit himself for it." 477 U.S. at 419 (citing Hawles, Remarks on the Trial of Mr. Charles Bateman, 11 How. ST. TR. $474,477(1685))$.

75 The ABA report put the issue this way:

[T] he offender should also have a meaningful understanding of what it means to be dead -in the sense that life is terminated and that the prisoner will not be "waking up" or otherwise continuing his existence. Deficient understanding of what it means to be dead can be associated with mental retardation and with delusional beliefs symptomatic of severe mental illness. These profound deficiencies in understanding associated with mental disability should not be trivialized or ignored by analogizing them to widely shared uncertainty among normal persons about the existence of some form of spiritual "life" after death or about the possibility of resurrection.

Recommendation and Report on the Death Penalty and Persons with Mental Disabilities, 30 MENTAL \& PHYSICAL DiSABILITY L. REP. 668, 676 (2006).

76440 F.3d 160 (4th Cir. 2006).

77 Id. at 191. 
measure of what a condemned prisoner must understand for fear of drawing the courts into scrutinizing the rationality of spiritual and religious beliefs about what happens after one dies. As judge Wilkins said in his dissenting opinion, however, the mere ability to say the words "execution" and "die" does not manifest even the most rudimentary understanding of the finality of death, and defining death as the end of one's physical existence for Ford purposes implies nothing one way or the other regarding the possibility of reincarnation or a spiritual afterlife. ${ }^{78}$

Another puzzle regarding the meaning of incompetence to be executed under Ford is what it means to be aware of the punishment one is "about to suffer." Consider the problem posed in Thompson v. Bell, ${ }^{79}$ now pending in the Sixth Circuit. $^{80}$ Uncontested evidence shows that Gregory Thompson suffers from severe mental illness with psychotic features and that he experiences multiple delusions, including a fixed belief that his conviction will be set aside and that he will not be executed. Even so, he recognizes that he has been convicted and sentenced to death for murder. The Tennessee courts as well as the federal district court concluded that he is "aware of his impeding execution and the reason for it," as required by Ford, and that his delusional belief that the execution will not be carried out is irrelevant to his competence for execution under Ford. ${ }^{81}$

Thompson relies heavily on Justice Powell's observation in Ford that "only if the defendant is aware that his death is approaching can he prepare himself for his passing." 82 Although the district court properly ruled that "ability to prepare oneself mentally and spiritually for one's death" is not part of the "test" for competence to be executed under Ford, ${ }^{83}$ Justice Powell's observation highlights why it is important to assure that the condemned prisoner is aware of the punishment that he is "about to suffer" before he is executed. ${ }^{84}$ A prisoner who is so deluded that he is certain that he will not be executed, even on the eve of the scheduled execution, is unaware of his mortal peril; executing him in this condition would be equivalent to executing a mentally ill prisoner who believes that he, the

\section{Id. at 183.}

79 Thompson v. Bell, No. 1:04-CV-177, 2006 WL 1195892 (E.D. Tenn. May 4, 2006) (memorandum opinion dismissing petition for writ of habeas corpus).

80 Thompson v. Bell, No. 06-5770 (6th Cir. June 19, 2007) (order granting a Certificate of Appealability on whether enactment of Tennessee Supreme Court Rule 39 is an extraordinary circumstance significant enough to reopen Thompson's original habeas petition).

${ }^{81}$ See Thompson v. Bell, No. 1:04-CV-177, 2006 WL 1195892 (E.D. Tenn. May 4, 2006); Thompson v. State, 134 S.W.3d 168 (Tenn. 2004).

82 Thompson, $2006 \mathrm{WL}$ at *22 (citing Ford v. Wainwright, 477 U.S. 399, 422 (1986)).

83 Id. at *22-23. See also Walton v. Johnson, 440 F.3d 160, 172 (4th Cir. 2006) (competence for execution did not require that prisoner have capacity to prepare himself mentally and spiritually for death).

84 Even the Tennessee Supreme Court's formulation of the Ford test requires that the offender be aware of his "impending execution." Thompson v. Bell, No. 1:04-CV-177, 2006 WL 1195892, at *7 (E.D. Tenn. May 4, 2006) (citing Van Tran v. State, 6 S.W.3d 257, 266 (Tenn. 1999)). 
executioner, the witnesses and all other participants are playing their assigned parts in a dramatic performance, pretending to carry out an execution.

Having said this, however, I do not mean to imply that unrealistic hopes of judicial or gubernatorial intervention, or even divine intervention, render a prisoner incompetent for execution. Thompson's incapacity to recognize the fact of his impending execution reveals a gross misunderstanding of reality attributable to severe mental illness, not the wishful thinking of a typically hopeful prisoner faced with imminent execution.

One advantage of the approach suggested here is that it clarifies Ford's conceptual location in the doctrinal landscape of the Eighth Amendment. At least three possibilities can be imagined. First, Justice Marshall's opinion in Ford implies that the common-law ban on executing presently incompetent prisoners falls in the category of punishments, such as breaking on the wheel, drawing and quartering, and the rack and thumbscrew that have long been forbidden because they are cruel or barbaric. ${ }^{85}$ However, this categorization is imperfect because the "cruelty" of execution in this context lies not in the punishment itself but in the barbarity of imposing it on particular prisoners. ${ }^{86}$ The emphasis on retribution in Ford and Panetti suggests a second doctrinal possibility-the ban on executing incompetent prisoners may amount to unconstitutionally excessive or disproportionate punishment, analogous to the imposition of the death penalty on offenders who were convicted of rape, ${ }^{87}$ lacked sufficient culpability at the time of the offense, ${ }^{88}$ who were under 18 at the time of the offense, ${ }^{89}$ or who are mentally retarded. ${ }^{90}$ This analogy is problematic, of course, because a death sentence is not excessive in relation to the seriousness of Panetti's crime and the Court never raises any question regarding his culpability at the time of offense. ${ }^{91}$ Is the Court

85 See, e.g., Chambers v. Florida, 309 U.S. 227 (1940); In re Kemmler, 136 U.S. 436 (1890).

86 For those forms of punishment banned at the time the Constitution was adopted, there is no need to address contemporary values. However, the Court has also held that the Eighth Amendment bans forms of punishment that were accepted at the time of its adoption if they now contravene the "evolving standards of decency that mark the progress of a civilized society," such as deprivation of citizenship. Trop v. Dulles, 356 U.S. 86, 101 (1958). The Eighth Amendment may also be understood to carry forward well-established limitations on punishment, whatever they are, but the ban on executing incompetent prisoners, even though well-established, might require a contemporary justification in light of the many safeguards that now prevent hasty executions. Even if no contemporary justification is needed to ground the common-law ban in the Eighth Amendment, the scope of the ban must be rooted in contemporary values, as Justice Kennedy implicitly recognized in Panetti. See generally Panetti v Quarterman, 127 S. Ct. 2842 (2007).

87 Coker v. Georgia, 433 U.S. 584, 592 (1977).

88 Enmund v. Florida, 458 U.S. 782, 797 (1982); see also Tison v. Arizona, 481 U.S. 137, $157-58$ (1987).

89 Roper v. Simmons, 543 U.S. 551, 574 (2005).

90 Atkins v. Virginia, 536 U.S. 304, 321 (2002).

91 Anyone familiar with Panetti's psychiatric history might well conclude that his severe mental illness significantly impaired his ability to exercise rational control over his behavior at the time of the murders, and that the death penalty is disproportionate to his culpability. See ABA 
holding that imposition of an otherwise permitted punishment on a deserving offender can become excessive if it no longer serves a "proper purpose" at the time of execution? ${ }^{92}$ However, even if executing incompetent prisoners does not serve a retributive purpose, Justice Kennedy never discusses the possibility that it could serve a deterrent purpose. ${ }^{93}$

The most persuasive approach is a straightforward "limiting principle" rationale-that even if it could be otherwise justified on deterrent, incapacitative, or even retributive grounds, executing presently incompetent prisoners is banned by the Eighth Amendment as a violation of human dignity-as a violation of the prisoner's right to be treated with respect as an individual person and not, as I said above, as a mere object of the State's effort to carry out its promises. ${ }^{94}$ There is much in Justice Marshall's rhetoric in Ford to support this view and it can be anchored securely in the core value of the Eighth Amendment ${ }^{95}$ and the fundamental principle of respect for persons that underlies the capital defendant's right to an individualized judgment regarding the suitability of the death penalty in his case. ${ }^{96}$ Nor does this approach require a commitment to any particular theory of retribution.

\section{COSTS AND BENEFITS}

However persuasive the argument for withholding execution of incompetent prisoners might be, the benefits of recognizing and administering such an exemption ${ }^{97}$ might be offset by its costs. I doubt that there is a significant risk of

Recommendation, supra note 2 , at $\ 1$. However, the sole issue before the Court concerns Panetti's mental condition at the time of execution, not his culpability at the time of the offense.

92 Panetti v. Quarterman, 127 S. Ct. 2842, 2860 (2007).

93 See Steiker, supra note 63. As Professor Steiker points out, the Court has vacillated wildly in its methodology in the line of cases addressing claims that the death penalty is disproportionate to the seriousness of the offense or the culpability of the offender.

94 One puzzle is whether the right may be waived. Presumably, the answer is yes. The prisoner has a right under the Eighth Amendment not to be executed while incompetent, but a condemned prisoner might say, in advance, while competent, that he would prefer to be executed while incompetent. Under the approach outlined in the text, the right would be waivable. However, under a strongly retributive rationale, the purpose of the punishment would not be served by executing the incompetent person, and it should be forbidden. Morally speaking, the competent prisoner may actually have a right to be executed, but the prisoner has neither a moral nor a legal right to be executed while incompetent.

95 See Trop v. Dulles, 356 U.S. 86, 100 (1958) ("The basic concept underlying the Eighth Amendment is nothing less than the dignity of man.").

96 See Woodson v. North Carolina, 428 U.S. 280, 303-05 (1976) (opinion of Stewart, Powell \& Stevens, JJ.)

97 I will assume that the sentence of a person found by a court to be incompetent for execution will be commuted, as required in Maryland and as recommended by the ABA and companion organizations. Commutation avoids the unseemly effort to medicate a prisoner for the sole purpose of enabling the State to execute him. I have discussed this problem in Richard J. Bonnie, HealingKilling Conflicts, Hastings Center RePort, May/June 1990, at 12. 
fabrication in this setting. It is almost certain that the prisoners whose claims receive a hard look will be offenders similar to Panetti-those with a history of severe mental disorder, whose diagnoses are uncontested, and who manifest acute symptoms of cognitive disorganization, hallucinations, or delusions. Although there is some risk of exaggerated symptoms, the dispute, as in Panetti, will usually concern the application of the legal standard to genuine impairments. It is possible that the "rational understanding" test, admittedly less determinate than a "formal understanding" test, will invite more claims and will lead to exemption in "too many" cases. I doubt that this will occur; very few claims are likely to be vindicated.

For purposes of argument, though, let us suppose that execution competence claims become a commonplace "last resort" for condemned prisoners who have any history of mental illness. That would surely increase the costs. Is it worth the effort?

The answer is decidedly yes. However, I would not rest my case exclusively on the offense to human dignity of executing presently incompetent prisoners. I think a stronger argument is that the Ford exemption provides a safety valve for correcting injustice at trial. Jurors all too often seem to discount mitigating claims of mental illness in the face of the intensity or brutality that may be associated with homicidal violence by mentally disordered offenders, and they may actually regard mental illness as an aggravating factor. Proportionality review of death sentences, as currently practiced in most states, fails to correct these distortions. Moreover, as Panetti's case shows, severely disturbed defendants often subvert all of the procedural safeguards our system affords them, frustrating or angering judges, prosecutors and jurors in the process. Viewed from this perspective, execution competence determinations provide a final judicial outlet for remedying mistakes in capital adjudications.

\section{A GLIMMER OF LIGHT?}

I return to the questions raised at the beginning of this paper. Viewed simply as a case about the proper test for assessing a prisoner's competence for execution, Panetti is not particularly important. Its attraction lies mainly in the opportunity to explore the reasons for exempting mentally ill prisoners from execution, a topic of interest exclusively to criminal law professors. However, Panetti also exposes two more substantial problems that should be of interest to everyone interested in the fair administration of the death penalty. One is the failure of the criminal justice system to take proper account of the effects of severe mental illness in capital adjudications, specifically by failing to assure a fair defense for defendants with mental disabilities, by failing to give morally appropriate mitigating effect to claims of diminished responsibility at the time of the crime, and by failing to correct these deficiencies in post-conviction proceedings. Those appalling failures are amply documented in Panetti. 
An even larger problem exposed by the Panetti litigation is the failure of the Supreme Court's capital sentencing jurisprudence. When a majority of the Supreme Court opted to reaffirm the constitutionality of capital punishment in 1976, it set out to develop and administer an aggressive "death is different" jurisprudence. As that effort continues to unfold, it is characterized by a rich body of principles and doctrines, together with an understandable unwillingness to enforce them aggressively by backstopping state courts, and by a Byzantine body of habeas law that insulates state court judgments from collateral attack.

Successful implementation of capital sentencing jurisprudence depends on aggressive efforts by state appellate courts to enforce the values and principles articulated by the Supreme Court as "the supreme law of the land." While some state appellate courts have taken this responsibility seriously, others, such as the appellate courts of Texas, have not. ${ }^{98}$ The Texas courts failed miserably here, right from the beginning of the pretrial process and all the way through the second postconviction proceedings. Yet, Panetti's death sentence would have been carried out if Justice Kennedy had followed his usual inclination to defer to state courts.

Four Justices are clearly not willing to abandon the Court's Eighth Amendment project. It so happens that Justice Kennedy joined them here. The key question is "Why?" I suspect that Justice Kennedy joined the "liberal' wing in this case because he recognizes, as the four dissenters may not, that the case reflected an utter disregard for the constitutional principles designed to take into account the clinical realities of severe mental illness - to prevent gross injustice at trial and inhumanity on death row. Whether this case reflects a glimmer of light in the darkness remains to be seen.

98 See, e.g., Abdul-Kabir v. Quarterman, 127 S. Ct. 1654 (2007); Smith v. Texas, 127 S. Ct. 1686 (2007); Penry v. Johnson, 532 U.S. 782 (2001). 
